\title{
Plant Integrity - The Important Factor of Adaptability to Stress Conditions
}

\author{
Ladislav Bláha and Tomáš Středa \\ Additional information is available at the end of the chapter
}

http://dx.doi.org/10.5772/62306

\begin{abstract}
Crop production, research of crop productivity, tolerance to abiotic and biotic stresses, plant disease, and pests all represent the problem of plant integrity. Plants represent an integrated system of units, which are responsible for its resistance to adverse environmental conditions on the basis of the evaluation of characteristics both aboveground and in the roots. This "complete unit" (root and shoot) has an influence on the formation of seeds, the quality of which may affect subsequent growth, development, and stress tolerance of the filial generation. Properties of the roots predominantly influence (especially at drought stress conditions) growth, development, and the metabolic processes in the aboveground part of the plant. The seed traits affect the filial generation root morphology at the beginning of the vegetation period (especially length, surface, depth of root penetration, and also root weight). In the biology of the seeds, roots, yield formation, stress tolerance, etc., attention needs to be paid to plant integrity and adaptability during variable environmental conditions. Every plant, and its traits, is a result of all the plant's activities. This is important for plant breeding. For example, it is possible to provide selection for cultivar traits at seed germination. Quality of the embryonic traits is important for subsequent growth and development. In the juvenile phase, and in later stages, the same genotype is still active. This is is among the main reasons for studying plant integrity.
\end{abstract}

Keywords: Plant integrity, abiotic stress, crop production, weather variability, seeds, roots

\section{Introduction}

The effect of plant integrity and of aboveground/belowground defense signaling on plant resistance to abiotic and biotic stresses is a basic and very important subject of contemporary scientific research. 
Profitable, stable crop varieties demonstrate superior traits for all types of observed characteristics in all environmental conditions (seeds, roots, shoots). Good varieties in ecologically different conditions usually have superior features for all types of analyzed traits. It is possible to state on the basis of whole plant metabolism, that plants create integrated system units, which are responsible for resistance to adverse environmental conditions on the basis of evaluation of characteristics of their aboveground parts and their roots. This "unit" (root and shoot) has an influence on the formation of seeds, which, by their quality, may affect the subsequent growth and development of the filial generation, and thus is also resistant to external conditions.

The earliest information about "physiological manifestations of plant integrity" was found in ancient Rome, in the era of Gaius Julius Caesar. Plant integrity, regarding the "functionally coordinated whole plant body", was first defined on the basis of scientific knowledge in the Czech Republic by Rudolf Dostál (1885-1973). Properties of the roots significantly affect (especially during drought conditions) growth, development in the aboveground part of the plant, and plant seed growth and development. From the opposite viewpoint, it is known that seed traits affect, in the filial generation, root morphology at the beginning of the vegetation period: especially length, surface, depth of root penetration, and also root weight.

The first description of seeds was presented by the Greek scholar Theophrastus (372-282 B.C.). The main development of seed science began in the 19th century [1]. Seed traits are factors, with different levels of importance, which are given by soil and weather conditions during the sowing and time of emergence. The processes and traits of germination and field emergence of a plant are very important for subsequent growth and development. Genotypes with good seed germination under unfavorable conditions develop, in the filial generation, larger root systems in field conditions. However, the most physiological experiments with green parts of plants do not take into account the fact that "half" of the metabolic processes in plants take place in the roots. This part of the plant has an important influence on the shoot traits and seed production.

Darwin expressed that "roots are as brain of plants", i.e. roots can be taken as a similar body to the brain. Currently, it is known that for transmission signals (changes of potential) between roots and the aboveground parts of the plant, plasmodesma are needed. The root system provides transmission information to other parts of the plant (shoots and seeds under development). Information about pathogen attack or physical stress can be transmitted to the other parts of the plant in order to begin as soon as possible the organisms defense - thanks again to plasmodesma. If the stress is repeated again, the reaction of the plant is more rapid, based upon "plant memory".

In the biology of the seed, especially in seed productions we need to pay attention to plant integrity and adaptability over variable environmental conditions. Adaptability (plasticity) is a feature that allows the plant to return to its original previous physiological state, i.e. to basic metabolic functions, after unusual environmental conditions. Adaptability is fixed on all chromosomes and can be identified in the early stages of growth. Adaptability in a broader sense includes seed quality, especially the quality of sprouting plants, root system adaptability, and issues relating postharvest physiological processes, including the physiological processes 
during storage. On the basis of entire plant physiology, it is possible to use more than 100 plant characteristics to improve adaptability under variable environmental conditions.

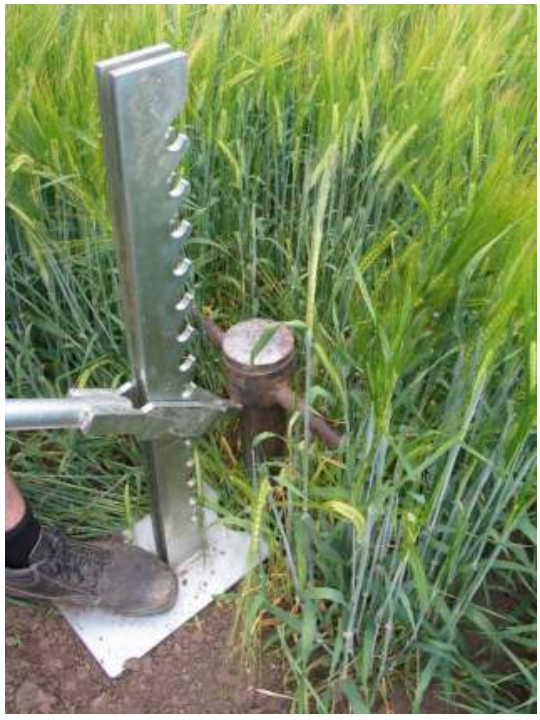

Figure 1. Sampling the root biomass for the evaluation of the relation between above and below ground parts of a plant.

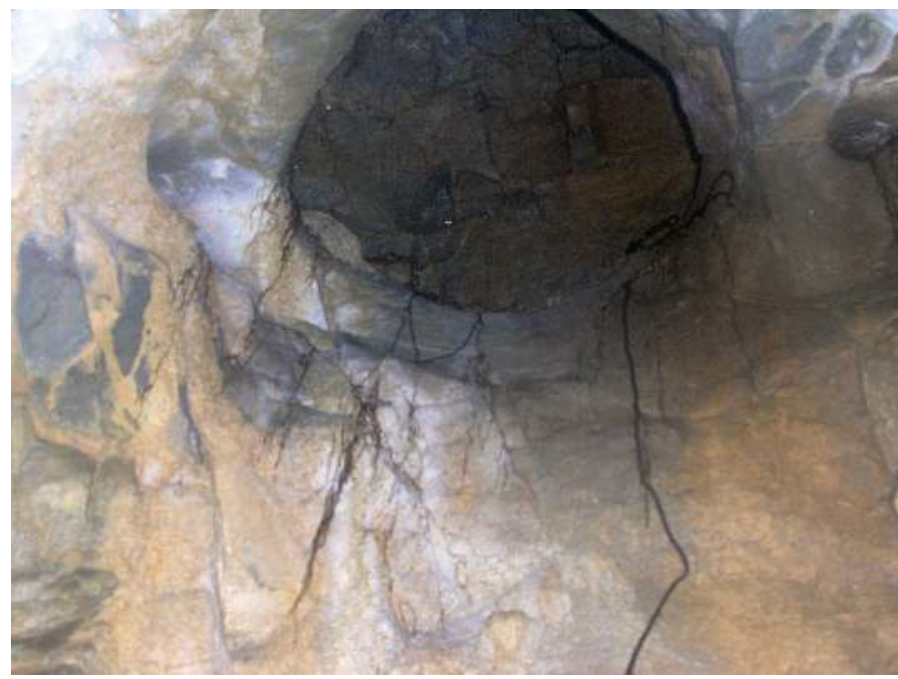

Figure 2. Plant roots in the interior of Kateřinská Cave (Moravian Karst, Czech Republic). 


\section{Main abiotic plant stresses in central Europe}

Abiotic stress is a main cause of reduced yield in the case of healthy plants. In this context, many scientific research projects have dealt with the impact of weather and climate change on agricultural crops. They were primarily focused on the impact of stress evaluation - especially drought and air and soil temperature extremes. The main current problems are lack of soil water or soil drought as well as high air temperatures. It has also been proved that there has been a prolongation of the growing season - 15 to 25 days - in central Europe in the last 20 years. This is accompanied also by an increasing probability of risk of vegetation frost. Concrete adaptation measures that would eliminate the impacts of climate change are still not a reality.

Monitoring of meteorological elements is crucial for the precise description of microclimatic conditions and their influence on plant physiological processes. The outcomes of microclimate monitoring provide valuable data for growth, plant protection, yield, and irrigation models as well as a wide range of other applications. Monitoring of air temperature and humidity as well as temperature and soil moisture and solar radiation should be an integral part of all growing trials - pot or field based. It is difficult to find any kind of cultivation experiment where the soil moisture and air temperature do not play important roles.

Globally, agriculture accounts for $80-90 \%$ of the freshwater used by humans. In many crop production systems such a water use is unsustainable. An interdisciplinary approach involving agronomical opportunities and plant breeding in order to deliver "more crop per drop" is needed [2]. In the field, the upper limit of water productivity for well-managed, disease-free, water-limited cereal crops is typically $20 \mathrm{~kg} \mathrm{ha}^{-1} \mathrm{~mm}^{-1}$ (grain yield per water used). Climate development in Europe since 1990 has been unfavorable for cereal yields because of heat stress during grain filling and drought during stem elongation. Drought during the generative phase decreases the number of based spikelets and grains. Another critical period is also flowering, when water shortage impact is worse than during other stages of development. During the stage of seed filling water stress disrupts the process of synthesis and storage of starch and storage proteins. It has been confirmed [3] that early drought reduces the number of offshoots and number of grains per ear. Late drought at the time of the development of leaves and grain filling causes leaves to age and their photosynthetically active surface decreases faster than in irrigated plants. Late drought negatively affects grain size.

Spring cereal yields decreased by $45-75 \mathrm{~kg} \mathrm{ha}^{-1}$ due to decreased precipitation of $10 \mathrm{~mm}$ [4]. The highest values of water requirement in plants were observed in the stages from shooting to heading, during an intensive increase of biomass. During this period, the plants utilized up to $5 \mathrm{~mm}$ of water per day. Seasonal deficits of precipitation during the growing season in central Poland were -145 and $-169 \mathrm{~mm}$ for barley and wheat, respectively. In the growing season they utilized from 293 to $314 \mathrm{~mm}$ of the soil water [5].

Moisture certainty analyses in the Czech Republic (central Europe) proved there was an increase in the driest areas and that drought event probability increased in during the 19612010 period [6]. An increase in air temperature above normal months and the loss of normal precipitation months were identified. An increase in temperature and precipitation extremes 
in the future, across climatic conditions and types of landscapes in the Czech Republic, was found [7]. The occurrence of meteorological drought, as well as the occurrence of hydrological, agronomic, physiological, socio-economic, and other kinds of drought is an important feature of the Czech climate. Lack of soil moisture is expected in the main growing season (approximately 200 days) when the rainfall does not exceed $340 \mathrm{~mm}$. In connection with the stress effects on yield and quality the most important indication for growers is the presence of agronomic drought. This is defined as a state where the amount of moisture in the soil is less than that required by a particular plant. Literature often defines agronomic drought as a decline in soil moisture below the permanent wilting point (i.e., approximately -1.5 $\mathrm{MPa}$ ) which stops water uptake and, subsequently, plants growing. It has been claimed [8] that the proportion of usable water - not reducing yields - varies according to crop type and stage of development between $45 \%$ and $75 \%$ of the available water holding capacity (AWHC). [9] use soil moisture in the root zone at $65 \%$ AWHC as a limiting value for barley before transpiration is reduced.

The availability of soil water, together with global radiation belong to the main agrometeorological elements which determine the transpiration performance of plants. Global radiation has a primary effect on the transpiration of plants, however, in the case of drought stress occurrence, one may expect a major influence to be played by soil moisture on the course of transpiration. A crop's reaction to a decrease in soil water capacity is different for different crop species. The high evapotranspiration requirements of the environment may cause a loss of soil water through excessive transpiration in non-sensitive plants.

Water shortage-induced stress often goes hand in hand with temperature stress. Transpiration is the main mechanism a plant has to protect itself against overheating. Leaf temperature increases with increase in air temperature. Effective use of water implies maximal soil moisture capture for transpiration, which also involves reduced non-stomatal transpiration and minimal water loss by soil evapotranspiration.

The dependence of maize transpiration on air temperature, air humidity, solar radiation, soil moisture, wind speed, and leaf temperature were quantified [10]. Significant relationships between transpiration, global radiation, and air temperature were found. Conclusive dependence of transpiration on leaf surface temperature and wind speed was found (Fig. 3-6). Transpiration in maize plants was significantly influenced by soil moisture under moderate and severe drought stress. The dependence of transpiration on meteorological elements decreased with increasing deficiency of water. A correlation between transpiration and plant dry matter weight, plant height, and weight of corn cob was found. These results will be utilized in an effort to make the calculations of evapotranspiration in computing models more accurate.

Breeding for maximal soil moisture capture for transpiration is therefore the most important target for yield improvement under drought stress. Conclusions have been made [11] that differences in the effective use of water expressed as different yields under the same conditions can be partly attributed to different root system sizes (RSS) (probably due to deeper rooting) and can be improved by breeding. A value of 55\% AWHC [12] has been suggested as a 
qualitative and not stressful value for all growth phases except at the beginning of flowering $(45 \%)$ and plant maturation.

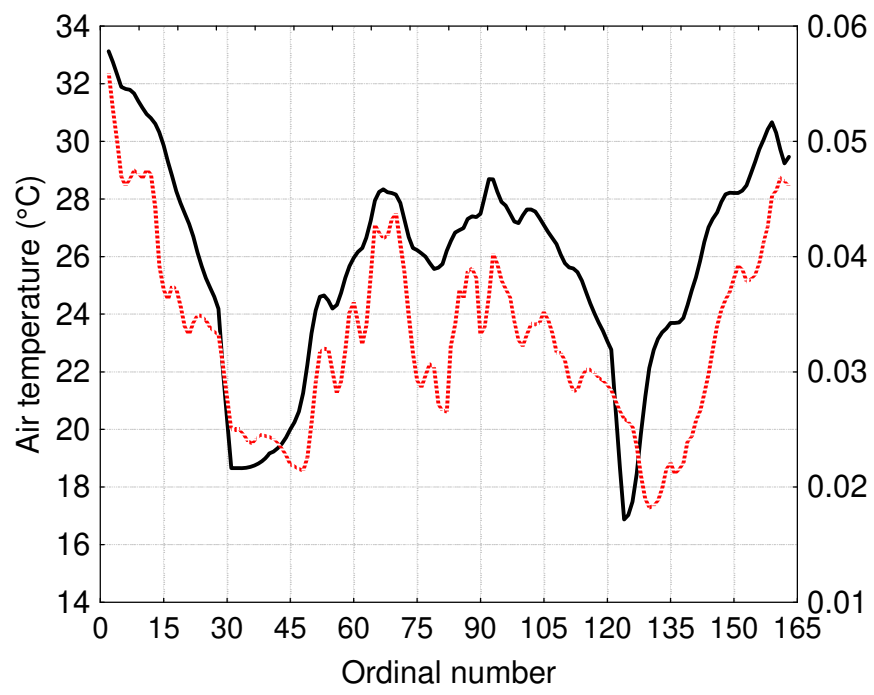

Figure 3. Course of sap flow (red line; $\mathrm{kg} \mathrm{h}^{-1}$ ) and its dependence on air temperature change (black line; ${ }^{\circ} \mathrm{C}$ ).

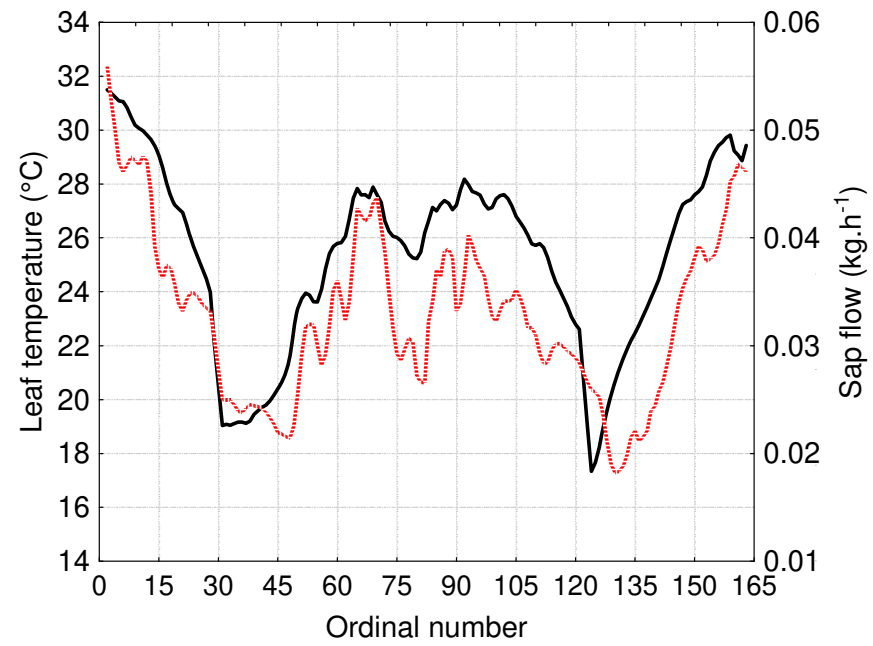

Figure 4. Course of sap flow (red line; $\mathrm{kg} \mathrm{h}^{-1}$ ) and its dependence on leaf surface temperature changes (black line; ${ }^{\circ} \mathrm{C}$ ). 


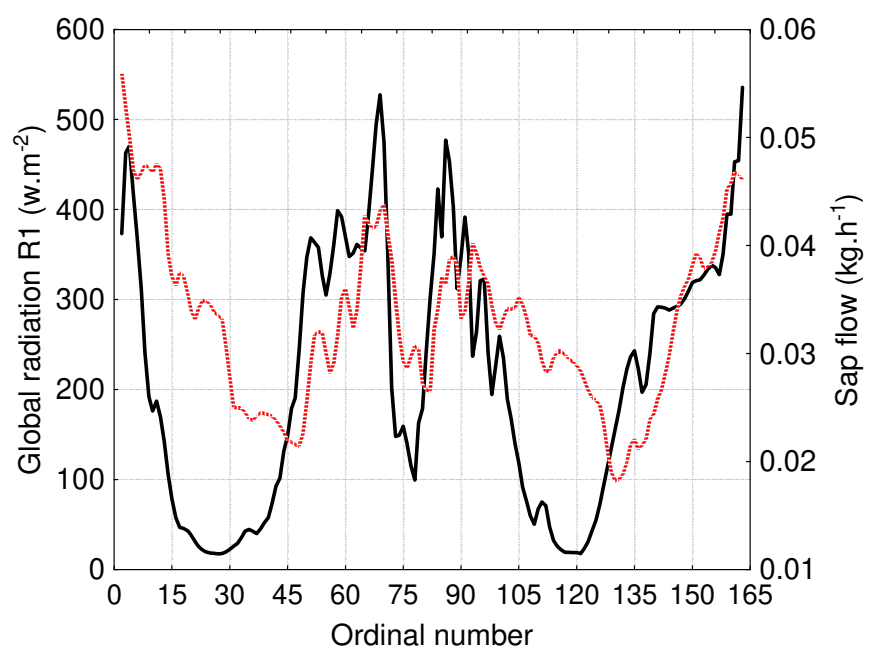

Figure 5. Course of sap flow (red line; $\mathrm{kg} \mathrm{h}^{-1}$ ) its dependence on global solar radiation intensity (black line; $\mathrm{W} \mathrm{m}^{-2}$ ).

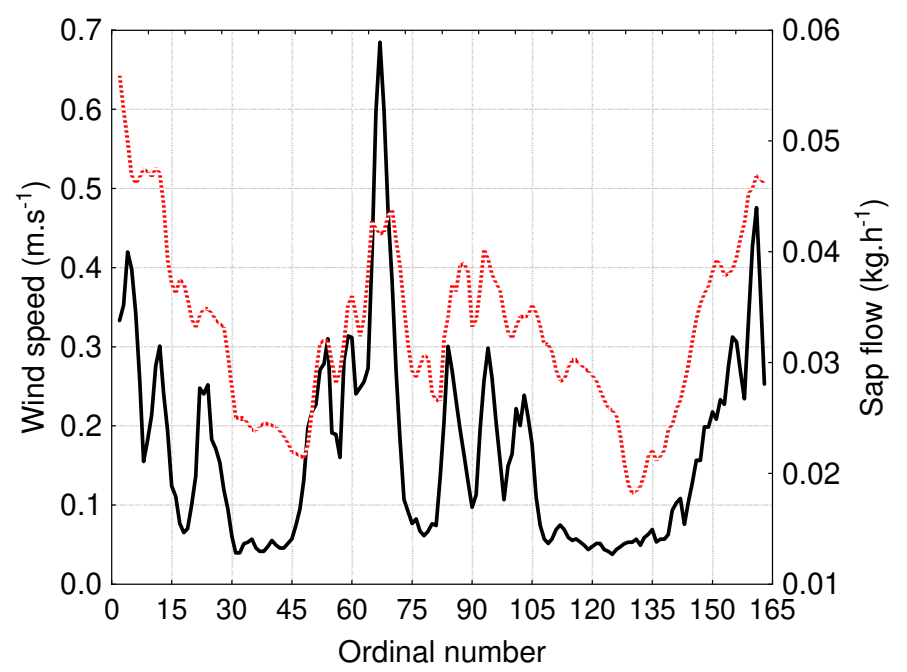

Figure 6. Course of sap flow (red line; $\mathrm{kg} \mathrm{h}^{-1}$ ) and its dependence on wind speed (black line; $\mathrm{m} \mathrm{s}^{-1}$ ). 
The amount of usable soil water was calculated using the agrometeorological model AVISO at 21 experimental sites for the period 1975-2007 (\% AWHC) [13]. A decrease in usable soil water (\% AWHC decrease up to $24 \%$ ) in a growing season was observed at 20 localities in the long-term trend. Statistically significant relationships were found between grain yield of spring barley and level of AWHC (\% AWHC). The optimum range for the amount of usable soil water for the production of spring barley $(65 \%-75 \%$ AWHC) was defined by long-term calculations of soil water in combination with a series of yield trials (Fig. 7).

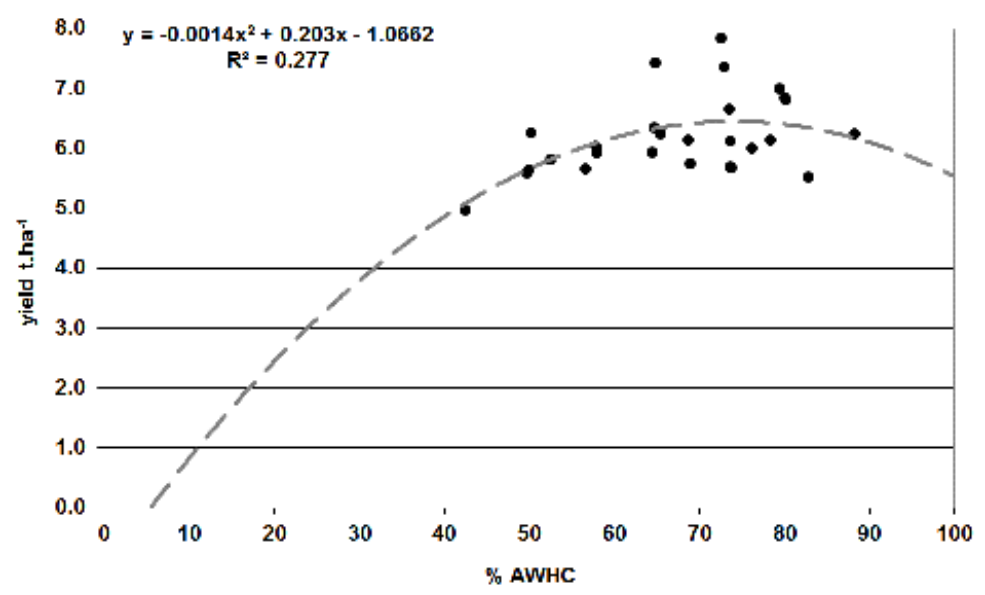

Figure 7. Relationship between the soil water supply (\% AWHC) and yield of spring barley grain.

Decreasing winter precipitation, increasing winter air temperatures, and increasing levels of $\mathrm{CO}_{2}$ in atmosphere were forecast as global climate changes for central Europe. The negative effects of water stress were partially compensated for by elevated $\mathrm{CO}_{2}$ concentration. Warmer winters could lead to northward expansion of the areas suitable for cropping. However, for crops with a determinate growth habit (e.g. cereals) acceleration of development under warmer conditions could reduce the time available for growth before maturity thereby tending to reduce grain yield. Combining these effects with the fertilizing effect of increasing atmospheric $\mathrm{CO}_{2}$ concentration, yield of wheat could be $30 \%-55 \%$ higher if there is enough water [14]. For non-determinate crops (e.g. root crops) the warmer climate would extend the growing season. However, there is the possibility that the more frequent, damagingly high summer temperature events could reduce yields of both cereal and root crops. Water can be limiting not only due to global warming but also due to higher yields caused by new varieties and by higher levels of agronomic inputs. Breeding for greater RSS could be therefore one of the strategies for avoiding the impact of water stress. For example, the grain yield of winter wheat varieties in dry years is generally positively correlated with RSS. In a dry year, the varieties that showed the greatest difference in RSS were found to exhibit a yield difference of $860 \mathrm{~kg}$ ha $^{-1}$, approximately translating to an additional use of $15 \mathrm{~mm}$ of subsoil water [11]. 


\section{Reasons why it is necessary to consider the integrity of plants in agriculture research}

\subsection{Seed vigor}

Seedling establishment is critical for production especially in stressed environments. The methods for the evaluation of seed germination are designed to have high levels of reproducibility and reliability; but worse than optimal conditions are often encountered in the field. For example, the germination percentage of barley (Hordeum vulgare L.) is an important character for both seed quality and malting quality. Although it is evaluated under optimal conditions for germination (laboratory temperatures and optimal moisture), it differs from germination in the soil and malting. In addition, seed lots that do not differ in germination may differ in emergence and storage potential. Seed vigor is generally described as the sum of the seed properties that determine the potential level of activity and performance of the seed during germination and seedling emergence [15]. Seed vigor is the ability of seeds to germinate and form the basis for future plant growth and development in standard and stressed conditions (drought, low temperatures, lack of nutrients). When soil conditions were unfavorable, the results of field emergence for wheat were more closely correlated with the direct stress vigor tests than laboratory germination [16]. The expression of seed vigor in field conditions and the translation to higher yields depends on the environment conditions.

Seed quality is of increasing importance as a result of climate development. Thus, seed vigor with regard to tolerance to drought and low temperatures as another potentially selectable trait which can be evaluated. The significance of this trait was documented by [17], who reported that an increase in the mean germination time due to poor seed vigor resulted in a significant loss in grain yield. The largest effect was found for winter wheat in which an increase in the mean germination time from 2.1 days to 3.6 days resulted in a relative loss in grain yield of $16 \%$. It is possible to conclude, that increasing the sowing rates of low-vigor seed lots did not secure an optimal grain yield.

High seed quality may be particularly important in low-input agriculture because poor early performance is not as readily compensated for later on by mineral fertilisers and pesticides as it is in conventional agriculture. Furthermore, quality and seed vigor are important factors for competitiveness against weeds: the seeds of low vigor resulted in a perceptible increase in weed biomass and decrease in crop yield.

Various seed germination tests, under the suboptimal conditions of temperature, oxygenation, and water potential of the medium, or undergoing accelerated ageing and controlled deterioration allows for the sensitive differentiation between seed lots. Germination and vigor also depends on multiple biochemical and molecular variables, and its characterization is expected to provide new markers of seed quality that can be used in breeding programmes.

Significant correlations between field emergence and laboratory tests of vigor have been published $[18,19,20]$. Higher precipitation shortly before the harvest decreased the seed vigor of spring barley significantly [21, 22]. Higher air temperatures during this period and during the period April-July increased vigor significantly. Seed germination and vigor were related 
to the parameters that are important for malting. The germination capacity of all lines was higher than their vigor and germination energy: $2.9 \%$ higher than vigor and $4.6 \%$ higher than the germination energy on average. This finding has confirmed the opinions of many authors who have reported that seed performance under optimal conditions is often higher in comparison to the seed performance in vigor experiments under stress and field conditions. Moreover, it has been confirmed that samples of the same germination capacity may have different vigor and storage potential.

The influence of late-terminal drought stress during grain filling on the germination and vigor of barley seeds has been studied [23]. Stress during the grain-filling stage had no effect on the standard germination test, but it obviously decreased the vigor of the seeds. The results indicate the positive influence of high air temperature during ripening and negative influence of high precipitation on the seed vigor.

The seed vigor of soybean, as evaluated as the mean percentage accelerated ageing rate, can be improved by breeding, whereas high yields were maintained because of the predominance of the general combined effects of both the seed vigor and yield [24]. The seed vigor, as evaluated by the cold test, showed estimates of the genetic response to selection in flax [25]. The three key traits of seed vigor in Brassica oleracea were rapid germination, rapid initial downward growth of the seedling, and a high potential for upward shoot growth in the soil with increasing impedance. This result suggests a strategy of stress avoidance. In addition, quantitative trait loci (i.e. QTL) were identified for marker and candidate gene identification. A few genomic regions (QTL) were identified for seedling vigor in rice. For these QTLs, significant genotype and environmental temperature interactions were found [26].

Our previous results [21] indicate the possibility of successful selection for higher seed vigor as an important factor of agronomic and malting quality, even in good years (vigor 93-95\%), for the traits given above. However, in the years with generally much lower vigor (61-86\%), the success could be more responsive because the effect of the variety prevailed over the effect of the environment for bad years. The vigor of 12 combinations from two locations was compared with vigor of their parents. Significant correlation was found between the vigor of the mothers and their progenies ( $r=0.832$; significant on $P \leq 0.01)$, between that of the fathers and their progenies $(r=0.882$; significant on $P \leq 0.01)$, and between the vigor of both parents and their progenies $(r=0.894$; significant on $P \leq 0.01)$. This is further evidence for potential effective breeding for vigor.

A lower seed vigor was correlated with a high occurrence of fungi (as indicated by ergosterol assays) and to a lower percentage of field emergence [27]. Vigor was also related to bread quality [28]. Grain samples with $80-90 \%$ vigor produced the greatest bread volume. Grain with vigor below or above this range produced less voluminous loafs of bread. High-quality varieties had a higher content of total polyphenols than did varieties of lower quality and the polyphenol content was correlated to vigor.

Cultivars of wheat with enhanced early vigor are still not commercially available. 


\subsection{Plant roots}

Contemporary knowledge confirms the possibility of selection for the root system and stress root tolerance on the basis of seedling stress tolerance, i.e. at time of the sprouting. It is possible also to evaluate characteristics of seeds and seedlings, i.e. provide selection, after plant hybridization of the plants on the basis of the seed and seedling traits, for seed quality an also classic selection in plant breeding.

Plants have developed different root system size (=RSS) during evolution and breeding. In dry and low levels of nutrients in the soil environments a greater RSS is found enabling plants to be more efficient with their use of water and nutrients from lower soil layers. Varieties of cereals with greater RSS better use soil water and nutrients in dry environments than varieties with smaller RSS. Relations between RSS and yield level, variation, and quality should be studied in a broader range of environments in central Europe for agricultural crops. However, yield is a polygenic trait and its level cannot be therefore explained by variation in only one factor (e.g. RSS). The level is limited primarily by the factor in minimum as described by Justus von Liebig. During vegetation, further limits occur either at different or similar times.

The use of natural resources of agricultural and forest ecosystems is much dependent on the functioning of plant roots. These provide several goods and services to society in the forms of, e.g., yield production, carbon sequestration, avoidance of nutrient release from the soil, alleviation of floods, and energy production. The functioning of plant roots is much less well known than that of the shoots, mostly due to methodological reasons. Only special new technology allows us to address the whole root systems quantitatively. Roots are exposed to several stresses (e.g. water stress by drought, soil frost, hypoxia, water shortage by competition) during their lifetime which may decline their capability to provide goods and services. This is especially the case for trees whose lifespan ranges from tens to hundreds of years. Soil conditions will change with climate warming in many locations, linked to a change in precipitation in summer and winter seasons. Therefore, knowledge of the limits for stress tolerance of the roots of herbaceous and woody plants is demanded for future projections.

The "Green Revolution" created dwarf varieties capable of responding to higher fertilizer inputs without lodging, but failed to reach resource-poor farmers. Crossing early greenrevolution wheat, with an $F_{2}$ of Norin 10 or Brevor, reduced root biomass. Later generation, semi-dwarf wheat showed genetic variation for root biomass, but some generations exhibited a further reduction in root size [29]. Beside a better use of available water resources, an improvement in the uptake efficiency of nutrients from mineral and organic fertilizers would have an important economic and ecological impact for a resource-efficient agricultural strategy. Varieties with greater roots could enable better use of available nutrients and water, as shown e.g. for phosphorus. The selected varieties with greater RSS should be better adapted to soil problems, like lowering of groundwater tables, acidification, loss of organic matter, soil compaction by heavy machines, etc. Varieties with greater RSS could be bred as catch crops or for the phytoremediation of nutrients and heavy metals. Wheat genotypes with superior root characteristics for efficient nutrient uptake, especially during the tillering and booting stages, should be developed in breeding programs to increase grain yield and minimize nitrate leaching [30]. 
The effect of water and nutrient application on yield has led to the overuse of these practices in the last decades. This misuse of irrigation and fertilizers is no longer sustainable, given the economic and environmental costs. Transpiration stream largely determines the availability of the mineral $\mathrm{N}$ in the rhizosphere. This makes our poor estimate of root densities a major obstacle to any precise assessment of nitrogen availability in fertilized crops. A larger investment by the crop in fine roots at depth in the soil, and less proliferation of roots in surface layers, would improve yields by accessing extra resources. The economic return on investment in roots for water capture was twice the investment for nitrogen capture. An early and more extensive horizontal growth of wheat roots in the $0.2-0.7-\mathrm{m}$ layer of the soil profile in glasshouses was found to improve substantially the uptake of $\mathrm{N}$ by vigorous lines [31]. There has been a long-standing interest in varietal differences in the uptake of nutrients, especially of $\mathrm{N}$ and $\mathrm{P}$, but progress has been slow in translating this into information that can be used in breeding. Root systems limit plant breeding [32].

Breeding for RSS as a strategy for improving yield stability and crop productivity under dry conditions however is still largely ignored in the breeding process, when it is not the breeding aim as such, e.g. for root crops like sugar beet. The main reason for this shortcoming in breeding for drought tolerance is the lack of a suitable method for evaluation of RSS. An improvement in water use is relevant when soil water remains available at maturity or when deep-rooted genotypes access water in the soil profile that is normally unavailable. At moderate drought, productivity of cereals can be improved by a more effective use of available water, i.e. by increasing the plants access to a higher soil volume by a deeper root system and eventually an increased rooting density in deeper soil. Varieties with a deep root system (Fig. 8) should have more opened stomata to cool the plants by transpiration, and therefore improve their tolerance to high temperatures [33].

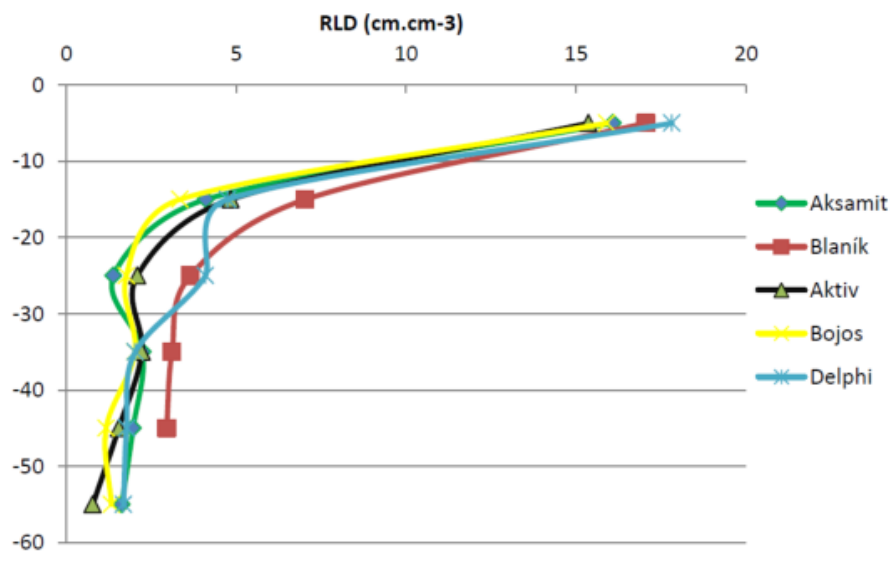

Figure 8. Vertical distribution of root length density (RLD) in spring barley varieties within the soil profile (Hrubčice, Czech Republic, 2012).

Better use of nutrients, including water, due to greater RSS, means: 
1. lower the contamination of the environment by them, i.e. lowering the content of nitrates, phosphates, etc. in groundwater, rivers, and seas;

2. a higher adaptability to some stresses during plant growth and development, e.g. limited water, heat, and nutrients;

3. avoidance of water shortage caused by a lowering of the water table in the soil;

4. a better recovery after damage by the limited stresses and after disease and pest attack;

5. higher yields when other growing conditions are not limiting. However, when growing conditions are limiting and water and nutrients are not available, a greater RSS could be a disadvantage;

6. suitability for ecological and/or low-input farming; and

7. lower costs for crop production.

Serious environmental impacts were associated with an enrichment of surface water and groundwater by nitrogen and phosphorus. Increased intensity of livestock rearing depends in Europe in particular on large amounts of imports of nutrients - rich feedstuff from countries outside Europe. In specific areas this has led to nutrient surpluses, which have contributed to problems such as eutrophication.

There are a number of works that assess interspecies or intervariety differences in the aboveground biomass production of crops. Only a small number of authors deal with quantitative and qualitative assessment of underground biomass in relation to the dynamics of nitrogen in soil. An appropriate measure for the use of nitrate nitrogen from the soil in the autumn is the inclusion of cover crops into crop rotation. Field trials [34,35] were executed to evaluate RSS in eight varieties of white mustard and five varieties of Phacelia on two locations, in three $\mathrm{BBCH}$ phases (i.e. international scale used to identify the phenological development stages of a plant) over two years. The relationship between RSS, aboveground biomass, and content of nitrogen in the soil was investigated. Phacelia featured on average a higher root/shoot ratio (0.45) than mustard (0.32), whereas the year impacted the ratio more than the production area type. In Phacelia a highly significant positive correlation was found between aboveground biomass and the amount of soil nitrate nitrogen. This phenomenon confirms that greater biomass production does not mean there is a lower soil nitrate nitrogen. A relationship between the RSS of mustard and the content of $\mathrm{NO}_{3}{ }^{-}$and $\mathrm{NH}_{4}{ }^{+}$ions in the soil after harvest was observed. RSS negatively correlated with the content of nitrate nitrogen in the soil, however, the correlation was statistically not significant. Evaluation across sites revealed a positive correlation between aboveground biomass and the amount of residual $\mathrm{NO}_{3}{ }^{-}$ions in the soil. On the other hand a significant negative correlation $(r=-0.81)$ of $\mathrm{RSS}_{\text {and }} \mathrm{NH}_{4}{ }^{+}$ions content was observed.

The effect of drought stress on the monitored traits of the root system and aboveground biomass of spring barley (Hordeum vulgare L.) was evaluated in a pot experiment by [36]. The characteristics of three varieties in a three-year observation in four different irrigation treatments were evaluated: length, surface area, weight of the root system (evaluated by the soilcore method with subsequent digital image analysis), the RSS (detected by measuring its 
electrical capacity), and dry matter yield of aboveground biomass and root biomass - the shoot ratio. Dry matter yield of aboveground biomass significantly correlates with the RSS $(r=0.700$; significant on $P \leq 0.01)$. The variability of root system traits was affected by year $(40 \%-50 \%)$, treatment $(10 \%-11 \%)$, and variety $(8 \%-14 \%)$.Weight ratio of aboveground biomass and root:shoot ratio were affected largely by variant $(28.1 \%$ and $42.0 \%$; significant effect). Year worked at least root: shoot (15.6\%; significant effect). Variants without stress produced the most above ground and below ground biomass. However, the root:shoot ratio was the lowest in this case.

\subsection{Examples of effective selection for greater root system}

RSS was one of the selection criteria in the breeding for dinitrogen fixation. Breeding of varieties with greater RSS (alfalfa Zuzana), and greater RSS and higher dinitrogen fixation (alfalfa Nitro, white clover Nivel) has been successful [37].

In cereals, root densities of $1.0-1.5 \mathrm{~cm} \mathrm{~cm}^{-3}$ are needed to extract plant available water from the soil, e.g. [38, 39]. Maize plants rarely achieve this below $70 \mathrm{~cm}$, but values of $3-5 \mathrm{~cm} \mathrm{~cm}^{-3}$ or more are common in the top $30 \mathrm{~cm}$ of soil. For better exploitation of available water, a better distribution of roots in the soil profile is preferable to partitioning more dry matter to roots [40]. A field trial with selected varieties of spring barley has been realized [36]. For five varieties RSS, its vertical distribution in the soil profile layers up to a $60-\mathrm{cm}$ depth, and grain yield were evaluated. The impact of locality, year, and variety on root system attributes was quantified. Highest values of root length density (RLD) were determined in the layer between $0 \mathrm{~cm}$ and $10 \mathrm{~cm}$ (Figure 8). A tendency to increase RLD in both research localities and in most varieties in the layer between $40 \mathrm{~cm}$ and to $60 \mathrm{~cm}$ was detected. A significant dependency of grain yield on RLD was only determined in the middle layers of the soil profile. In wet years a significant negative correlation was determined.

The RSS has been found to be a genetic trait, and some specific genes have been observed to control this property. In wild barley, the gene Hsdr4, involved in water-stress tolerance, was located on chromosome $3 \mathrm{H}$ near sdw1. This was identified as a marker of QTL for great RSS [41]. Therefore, the RSS and drought tolerance per se maybe linked.

The isolation of intact living root systems from soil in the field has not yet been published and seems impossible. This difficulty is evidenced in many observations. Biomass estimates from minirhizotrons indicate that the $<0.25 \mathrm{~mm}$ diameter roots (Fig. 9) account for nearly $95 \%$ of the total root length [42]. Root separation using a sieve with a $0.5-\mathrm{mm}$ mesh screen led to a marked underestimation of root length density and root biomass. Values up to three times higher were observed when using a 0.2-mm mesh screen in comparison to a 0.5-mm screen [43]. Ex situ methods are expensive and connected with relatively high experimental error. More progressive are in situ methods, in particular use of electric capacitance. Comparison of this method with the ex situ soil-core method found a good correlation. The electric capacitance can be therefore recommended as a quick and cheap method, which enables repeated evaluation of vegetation and retains the evaluated plants until harvest. 
The capability "to see" the roots in the soil plays a key role in the evaluation of the potential of herbaceous and woody plants to produce goods and services for society and in the detection of the stress thresholds of roots. From a functional point of view, fine roots (Fig. 9) are the most important for plants. Thus, a method that gives a measure of the root surface area for absorbing water and nutrients would be valuable and it would offer wide applications for users of the natural resources of plant/forest ecosystems.

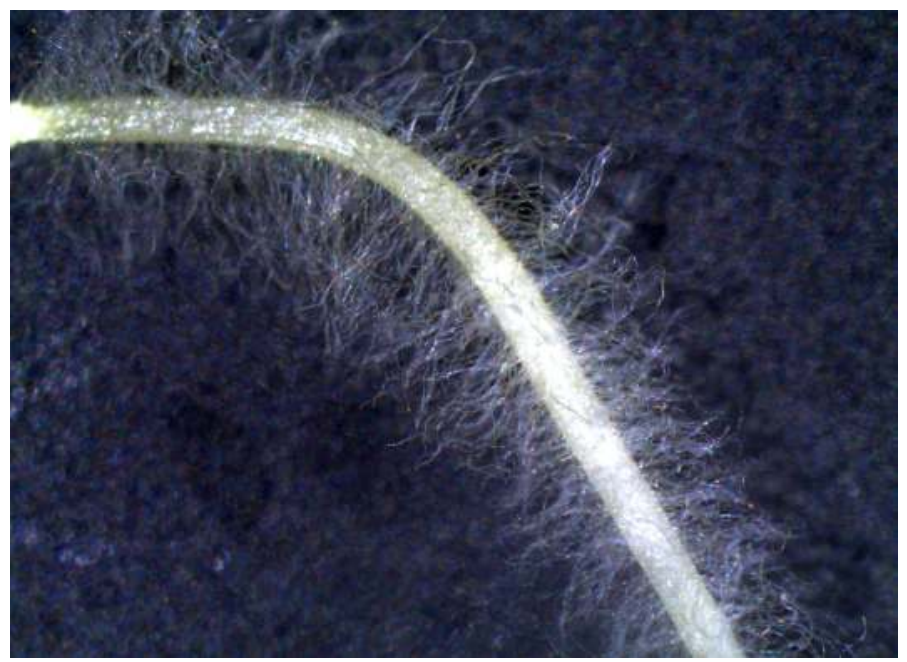

Figure 9. Measurement of the finest structures of a root system is possible using the method of electrical capacitance.

Wheat (Triticum aestivum L.) has been systematically bred for about 200 years. However, this breeding has been done using only aboveground plant parts. We evaluated previously the roots of 18 wheat populations [44]. The RSS was evaluated by its electrical capacitance directly in the field (in situ). The RSS of plants in third and fourth generations were evaluated during shooting and heading. In these evaluations plants were selected for large and small root systems. In dry environments, the progeny of plants with large and small root system had yields of 17.1 and 10.9 grams per plant in the third generation and 18.5 and 10.0 grams per plant in the fourth generation (Fig. 10). The selection process showed a greater response for larger root system size. Selection for higher wheat RSS can be easily used to breed for drought tolerance and higher efficiency of water and fertilizer use.

The study [45] introduces the evaluation of RSS for the breeding of spring barley, in particular for drought tolerance. The aim of this study was to present the method of RSS evaluation and show it in practical use, in particular in relation to drought tolerance. The varieties of spring barley were evaluated for RSS by its electrical capacity. The RSS was compared with the grain yield and grain quality of the varieties at 7-19 stations each year. Varieties with a greater RSS had a significantly higher yield in the dry part of the year. Varieties with a greater RSS had significantly higher contents of starch, saccharide extracts, and malt extracts, as well as higher 


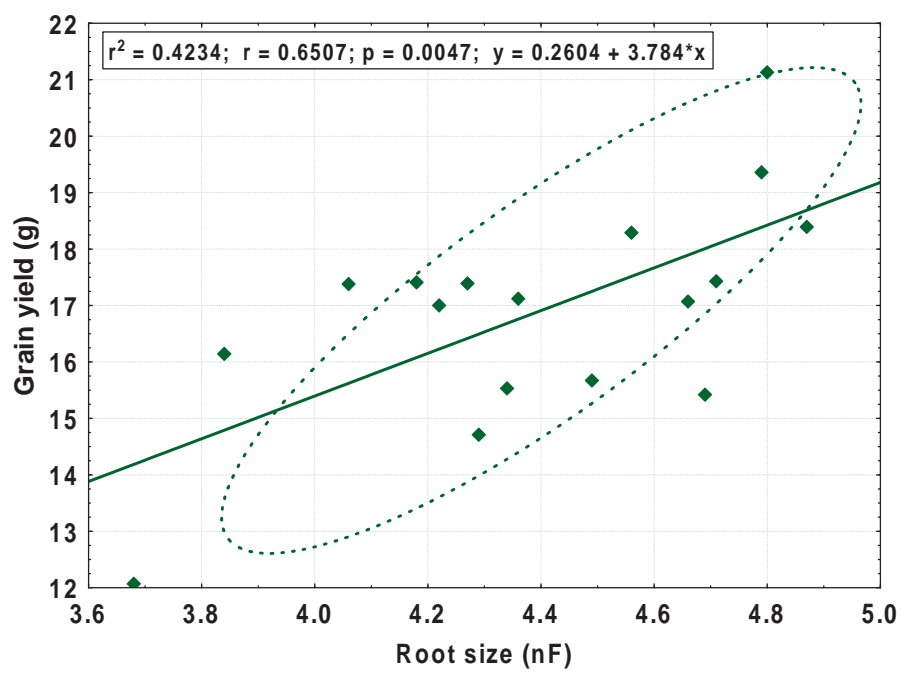

Figure 10. Regression relationship of the wheat grain yield on RSS as averaged from three locations (published in [44]).

yields of protein and starch in dry environments. It can be concluded that a small RSS is related to a low grain yield and malt quality in dry environments, even in genetically diverse varieties.
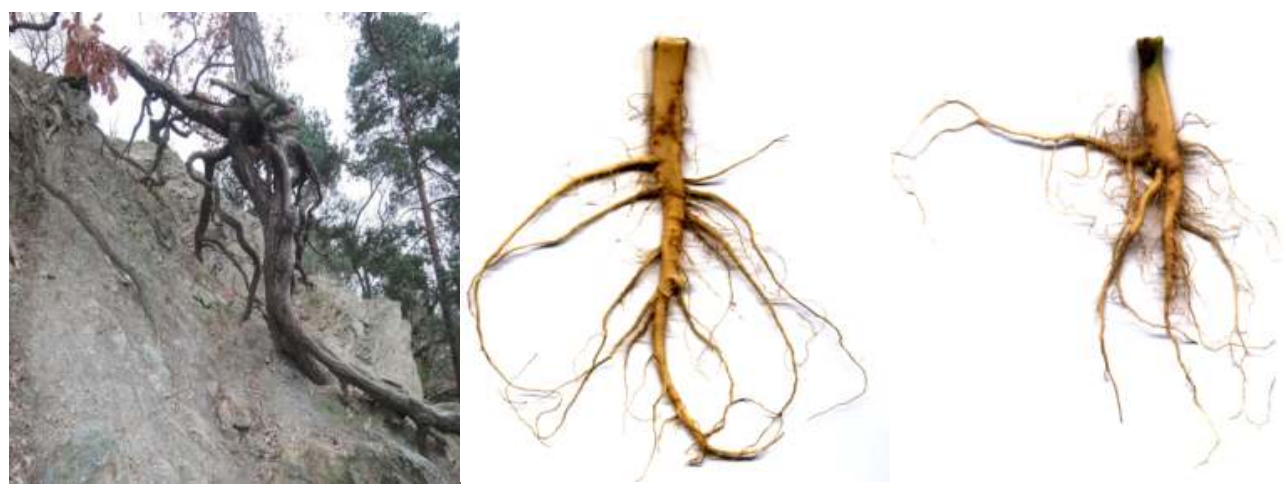

Figure 11. The root is the most sensitive organ of the plant. On the left: tree sample Pinus silvestris (Scots pine), standing on the main root, on the $4 \mathrm{~m}$ height, due to influence of strong soil erosion. These trees have on the basis of measurements at least twice as large a root system compared to those in a conventional environment. In the other two images are oil rape roots. The left of these images is a root located from a relatively dry, well-prepared soil. The right of these images shows a root from compacted, moist soil. Such changes have an effect on the metabolism of plants, yield, seed quality, stress resistance, i.e. not only variety, provenance, and method of seed storage. In addition, the quality of soil preparation (at field crops) has a large influence.

The relevance and response to selection for greater RSS of spring barley in field conditions has been studied [46]. The effect of selection in 12 barley populations developed by mutual crossing 
of 4 parents in the $\mathrm{F}_{3}$ generation as a response to the selection in the preceding generation $\mathrm{F}_{2}$, for great and small RSS was evaluated. The selection was effective. The average difference in the parental segregating generation was +40 and $-43 \%$, and in progeny +4 and $-2 \%$, respectively. Grain yield responded two times more to the selection (plants with a root size greater by $3.9 \%$ had higher yield of $8.1 \%$ ). Root size was found to be related to grain yield. Some varieties donated greater, some smaller roots into progeny. It was shown that the selection for RSS was effective and responsive (more for greater than for smaller roots) in a similar way as for grain yield and can be therefore used in practical breeding.

\section{Importance of plant integrity in crop research}

Plant integrity looks like as a "very easy and expanded topic," but the reality is very different. "Thanks" to the rigid specialization of scientists, we are losing a holistic view of plants. It is necessary to sense a plant in its entire complexity - both roots and shoots, as well as across their life cycles. Complex research, i.e. the connection of biology, plant nutrition, ecology, and other disciplines, is hardly observable in most scientific work. Only such an integrated approach can allow us to reach the correct interpretations for experimental results [47-54]. For example, when interaction of three or more stressors exists, there can be a lower or higher effect of stressors (compensated through the course of metabolism, etc.). The reason is the influence of individual factors on metabolism and their possible antagonistic influences. Stressors always have pleiotropic effects on a plant, and influence on many genes. Therefore, it is very important to test the adaptability of new breeding materials by utilizing extreme conditions in more locations, such as in ICARDA (The International Center for Agriculture Research in the Dry Areas) and CIMMYT (International Maize and Wheat Improvement Center) in Mexico [54, 55].

Currently, research is booming for the use of model, standard plants (Arabidopsis etc.). It is desirable that agricultural research is conducted with crops and not with so-called model species. The reasons for this requirement is both practical and physiological (diversity of metabolism). If, for example, Arabidopsis is used as a "model plant" for oilseed rape, because it is (on the basis of a physiological viewpoint) a similar plant with regards to its metabolic functions, then why not start research work straight away with oilseed rape?

There is also other problem. The differences between biological and agricultural research has increased in many cases. This phenomenon can also be observed in the relationship between contemporary agricultural research and its practical applications. Narrow research specialization predominates strongly, and the differences between biological and agricultural research has increased in many research areas. There is a relatively significant lack of new methods for the analysis of this problem. To be honest, lot of different types of internal plant signals, i.e., the transport of information in plant metabolism and their interconnection, memory of plants, and importance of plant neurobiology is also neglected [56].

Productive genotypes have a more efficient metabolic activity throughout all vegetation, with faster spring root growth and better plant cover affecting their subsequent growth and 
development. In our experiments, the influence of provenance was greater than that of variety (this is not a rule, it may be the opposite due to differences between varieties and locations at each experiment). Provenance has a very significant influence on the physiological characteristics of seeds, an even greater influence than seed weight and germination. The results confirm the importance of quality seeds to the cultivation of field crops and especially highlights the importance of plant integrity [57-62]. For example, analysis of the effect of variety and provenance of oilseed rape seeds (Brassica napus L. ssp. oleifera) on germination under different temperature conditions was provided. The obtained results confirm the importance of seed provenance and emphasize a preference for high-quality seeds. It is known that good seed vigor and provenance guarantees not only better field emergence, growth, and development of overall resistance to stressors (drought, high temperature), but also has a significant impact on seed yield in the subsequent generation (according to better overwintering).

There are several ways to improve the resistance and tolerance (adaptability) of plants to the variable environmental stress conditions with regard to the basis of the whole plant physiology.

The last physiological studies on the rape plant integrity and plasticity have shown, that the crop "responds" to stressors by more than 100 of currently known and measured physiological traits (as mentioned in the previous section of this chapter). There is possibility to use this phenomenon in plant breeding. Selected basic traits of seeds as a vigor, germination percentage, emergence, and stress tolerance of germinated seeds to high and low temperatures has significant influence on the yield of winter oilseed rape varieties [57-63], see below. These problems require more detailed analysis (64-67). Adaptable varieties have a wider possibility for growth and development in field conditions. Unfortunately, the current system of approving new varieties in many European countries is not heading in the direction of adaptable varieties, but rather in the direction of morphological homogeneity of the genetic material.

\subsection{The results of experiments with the oil rapeseeds}

\begin{tabular}{ccc}
\hline Genotype & Country of origin & Company origin \\
\hline Californium & France & Monsanto SAS \\
\hline Viking & Germany & NPZ (Norddeutsche Pflanzenzucht) \\
\hline Navajo & Great Britain & CPB Twyford Ltd \\
\hline OP 4947/07 & Czech Republic & Oseva PRO, s.r.o. \\
\hline Cadeli & France & Monsanto SAS \\
\hline Grizzly & France & Société RAGT 2n \\
\hline ČŽL 20 & China & Breeding material \\
\hline Labrador & France & SCA Adrien Momont et Fils
\end{tabular}

Table 1. Oil rapeseed cultivars at additional tests 
On the basis of laboratory additional tests with the selected cultivars (Tab. 1) the following results supporting the importance of the integrity of plants were obtained:

1. It is possible to eliminate, at the seed level, genotypes (initial breeding materials and cultivars) which do not tolerate extreme temperature and temperature changes during germination, have low water use efficiency, and are intolerant to abiotic stresses.

2. It was confirmed that these genotypes also have poor field emergence and initial growth of roots with implications for a further vegetation period, mainly for overwintering and spring regeneration which has influence on the yield.

3. This test method represents a tool for the screening of genetic resources with resistance to abiotic stress and this technology process is acceptable also for other crops.

Presented results were confirmed in the other rapeseed varieties (36 cultivars). Important obtained relationships are given in Tab. 2.

\begin{tabular}{l}
\hline Seed germination after exposure to cold temperatures for three days after the saturation of \\
seeds by water - simulating the impact of early frosts $\left(20^{\circ} \mathrm{C} / 12 \mathrm{hr}\right.$ a day, and $-3^{\circ} \mathrm{C} / 12 \mathrm{hr}$ a \\
night) \\
\hline Seed germination after exposure to high temperatures for three days after the saturation of \\
seeds by water - simulating the impact of high temperature $\left(30^{\circ} \mathrm{C} / 12 \mathrm{hr}\right.$ a day, and $20^{\circ} \mathrm{C} / 12 \mathrm{hr}+0.47^{*}$ \\
\begin{tabular}{ll} 
a night) & $+0.78^{* *}$ \\
\hline Influence of the locality (provenance) & $+0.68^{* *}$ \\
\hline Influence of the cultivar & $+0.35^{*}$ \\
\hline Efficiency of water utilization (water content required for germination) at standard & $+0.88^{* *}$ \\
\hline conditions during sprouting & +0.25 \\
\hline Efficiency of water utilization at high-temperature conditions during sprouting
\end{tabular} \\
\hline Efficiency of water utilization at low-temperature conditions during sprouting
\end{tabular}

Note: Stress tolerant seeds at time of sprouting are one of the lot of guarantors of the of quality crops establishment during growth and development and for winter survival.

**Statistical significance at $1 \%$; $*$ Statistical significance at $5 \%$

Table 2. Correlation coefficients: seed physiological traits and the yield.

However, one very important problem in plant experiments remains. There is the possibility to select pairs of cultivars with different traits and for simplification from the same latitude it is possible to obtain many conclusions. In this case there is a random drift of results. If we use large groups of cultivars it is possible to obtain, for different physiological types, common and repeatable conclusions.

The cultivars used for scientific experiments are not often appropriate for the analysed target. Shortly: There is in lot of "physiological experiments" with comparison of only two contrasting 
genotypes (varieties). It is very little number for finding general dependencies. (Then there plays the role random drift as mentioned). This type of scientific work has both physiological and genetic aspects, logical reasoning during the writing of scientific articles, and is at a high level; we can read a productive scientific article, but the practical application of the results for plant production and breeding then becomes impossible. It is not possible to draw general conclusions based on the analysis of two genotypes especially if whole plant physiology is important to the solution of the problem.

\section{Conclusions}

It is possible to provide selection for cultivar resistance to stress already at the seed germination stage and on the quality of plant root systems. Quality of the embryonic roots is important for the following growth and root development. Why does this possibility exists? The answer is because in the juvenile phase and in later stages, the same genotype is still active.

The effect of plant integrity and of aboveground-belowground defense signaling on plant resistance against abiotic stresses (and also pathogens) is important and a relatively new subject of scientific research. Biochemical analysis has unequivocally proven that plant defense responses to stress and pathogen infection differ between whole intact plants and detached plant parts (leaves, roots, stems, etc.). Therefore, the question arises - which type of scientific work will reflect reality more realistically? It is possible to conclude that it is research on the basis of plant integrity.

\section{Acknowledgements}

This work was supported by the project National Agency for Agricultural Research (NAZV) no. QJ1510098 “New breeding lines of winter wheat for a more efficient use of inputs and with higher stress resistance" and by project of Ministry of Agriculture of the Czech Republic no. MZe RO0414.

\section{Author details}

Ladislav Bláha ${ }^{1^{*}}$ and Tomáš Středa ${ }^{2}$

*Address all correspondence to: 1blaha@vurv.cz

1 Crop Research Institute, Praha 6 - Ruzyně, Division of Crop Genetics and Breeding, Czech Republic

2 Mendel University in Brno, Department of Crop Science, Breeding and Plant Medicine, Brno, Czech Republic 


\section{References}

[1] Black, M. Seed research - Past, present and future. Recent Advances in the Development and Germination of Seeds, NATO ASI Series, 1989, 187, 1-6.

[2] Davies, W. J., Zhang, J., Yang, J., Dodd, I. C. Novel crop science to improve yield and resource use efficiency in water-limited agriculture. The Journal of Agricultural Science, 2011, 149, 123-131.

[3] Lawlor, D. W., Day, W., Johnston, A. E., Legg, B. J., Parkinson, K. J. Growth of spring barley under drought: crop development, photosynthesis, dry-matter accumulation and nutrient content. The Journal of Agricultural Science, 1981, 96, 167-186.

[4] Peltonen-Sainio, P, Jauhiainen, L, Hakala, K. Crop responses to temperature and precipitation according to long-term multi-location trials at high-latitude conditions. Journal of Agricultural Science, 2011, 149, 49-62.

[5] Martyniak, L. Response of spring cereals to a deficit of atmospheric precipitation in the particular stages of plant growth and development. Agricultural Water Management, 2008, 95, 171-178.

[6] Středová, H., Chuchma, F., Středa, T. Climatic factors of soil estimated system. In International Scientific Conference on Bioclimate - Source and Limit of Social Development. Topolcianky, Slovakia. Nitra: SPU v Nitre, 2011, 137-138.

[7] Mužíková, B., Vlček, V., Středa, T. Tendencies of climatic extremes occurrence in different Moravian regions and landscape types. Acta Universitatis Agriculturae et Silviculturae Mendelianae Brunensis, 2011, 59, 5, 169-178.

[8] Spitz, P., Zavadil, J., Hemerka, I. Metodika řízení závlahového režimu plodin výpočetním programem ZAPROG 1. VÚMOP, Praha. 2007.

[9] Jamieson, P. D., Francis, G. S., Wilson, D. R., Martin, R. J. Effects of water deficits on evapotranspiration from barley. Agricultural and Forest Meteorology, 1995, 76, 41-58.

[10] Klimešová, J., Středová, H., Středa, T. Maize transpiration in response to meteorological conditions. Contributions to Geophysics and Geodesy, 2013, 43, 3, 225-236.

[11] Středa, T., Dostál, V., Horáková, V., Chloupek, O. Effective use of water by wheat varieties with different root system sizes in rain-fed experiments in Central Europe. Agricultural Water Management, 2012, 104, 2, 203-209.

[12] Doorenbos, J., Pruitt, W. O. Guidelines for predicting crop water requirements. FAO Irrigation and Drainage Paper 24, Food and Agriculture Organization, Rome. 1975.

[13] Středa, T., Středová, H., Kohut, M., Rožnovský, J. Yield of spring barley in dependence of soil moisture balance. In Tagungsband der 61. Jahrestagung der Vereinigung der Pflanzenzüchter und Saatgutkaufleute Österreichs. Raumberg-Gumpenstein: LFZ Raumberg-Gumpenstein, 2011, 171-174. 
[14] Eitzinger, J., Žalud, Z., Alexandrov, V., van Diepen, C. A., Trnka, M., Dubrovský, M., Semerádová, D., Oberforster, M. A local simulation study on the impact of climate change on winter wheat production in north-eastern Austria. Bodenkultur, 2001, 52, 279-292.

[15] Perry, D. A. Report of the vigour test committee 1974-1977. Seed Science and Technology, 1978, 6, 159-181.

[16] Hampton, J. G. The relationship between field emergence, laboratory germination, and vigour testing of New Zealand seed wheat lines. New Zealand Journal of Experimental Agriculture, 1981 9, 191-197.

[17] Pedersen, L. H., Jorgensen, P. E., Poulsen, I. Effects of seed vigor and dormancy on field emergence, development and grain yield of winter wheat (Triticum aestivum L.) and winter barley (Hordeum vulgare L.). Seed Science and Technology, 1993, 21, 159-178.

[18] McKenzie, K. S., Rutger, J. N., Peterson, M. L. Relation of seedling vigor to semidwarfism, early maturity, and pubescence in closely related rice lines. Crop Science, 1980, 20, 2, 169-172.

[19] Štastný, J., Pazderů, K. Evaluation of winter wheat (Triticum aestivum L.) seed quality and seed quality stability in relation to varieties and environmental conditions. Journal of Agrobiology, 2008, 25, 2, 153-161.

[20] Jones, D. B., Peterson, M. L. Rice seedling-vigor at sub-optimal temperatures. Crop Science, 1976, 16, 1, 102-105.

[21] Ullmannová, K., Středa, T., Chloupek, O. Use of barley seed vigour to discriminate drought and cold tolerance in crop years with high seed vigour and low trait variation. Plant Breeding, 2013, 132, 3, 295-298.

[22] Bodner, G., Ullmannová, K., Středa, T. Prospects of selection for barley seed vigour as a precondition for stand emergence under dry condition. Kvasný průmysl, 2013, 59, 9, 238-241.

[23] Samarah, N., Alqudah, A. Effects of late-terminal drought stress on seed germination and vigor of barley (Hordeum vulgare L.). Archives of Agronomy and Soil Science, 2011, $57,27-32$.

[24] Cho, Y., Scott, R. A. Combining ability of seed vigor and seed yield in soybean. Euphytica, 2000, 112, 145-150.

[25] Saeidi, G. Genetic variation and heritability for germination, seed vigour and field emergence in brown and yellow-seeded genotypes of flax. International Journal of Plant Production, 2008, 2, 15-22.

[26] Zhang, Z. H., Qu, X. S., Wan, S., Chen, L.H., Zhu, Y.G. Comparison of QTL controlling seedling vigour under different temperature conditions using recombinant inbred lines in rice (Oryza sativa). Annals of Botany, 2005, 95, 423-429. 
[27] Chloupek, O., Hrstková, P., Jurečka, D. Tolerance of barley seed germination to coldand drought-stress expressed as seed vigour. Plant Breeding, 2003, 122, 199-203.

[28] Chloupek, O., Both, Z., Dostál, V., Hrstková, P., Středa, T., Betsche, T., Hrušková, M., Horáková, V. Better bread from vigorous grain? Czech Journal of Food Sciences, 2008, $26,402-412$.

[29] Waines, J. G., Ehdaie, B. Domestication and crop physiology: roots of green-revolution wheat. Annals of Botany, 2007, 100, 991-998.

[30] Ehdaie, B., Merhaut, D. J., Ahmadian, S., Hoops, A. C., Khuong, T., Layne, A. P., Waines, J. G. Root system size influences water-nutrient uptake and nitrate leaching potential in wheat. Journal of Agronomy and Crop Science, 2010, 196, 455-466.

[31] Liao, M. T., Palta, J. A., Fillery, I. R. P. Root characteristics of vigorous wheat improve early nitrogen uptake. Australian Journal of Agricultural Research, 2006, 57, 1097-1107.

[32] Gregory, P. Plant roots. Oxford: Blackwell Publishing, Wiley Online, Library 2006, 318.

[33] Klimešová, J., Středa, T. Agrometeorological and biological aspects of maize transpiration. In Mendel and bioclimatology. Conference proceedings. Brno: Masaryk University, 2014, 189-198.

[34] Hajzler, M., Klimešová, J., Středa, T. Biomass production of white mustard (Sinapis alba L.) varieties in relation to the root system size. In 62. Tagung der Vereinigung der Pflanzenzüchter und Saatgutkaufleute Österreichs. Raumberg-Gumpenstein: Lehr- und Forschungszentrum für Landwirtschaft, 2012, 105-108.

[35] Hajzler, M., Klimešová, J., Středa, T., Vejražka, K., Mareček, V., Cholastová, T. Root system production and aboveground biomass production of chosen cover crops. World Academy of Science, Engineering and Technology, 2012, 69, 713-718.

[36] Klimešová, J., Středa, T. Distribution of barley root biomass in soil profile. In MendelNet 2013 - Proceedings of International PhD Students Conference. Faculty of Agronomy: Mendel University in Brno Czech Republic, 2013, 69-74.

[37] Chloupek, O., Babinec, J., Holubář, J. Development and evaluation of new synthetic varieties of Lucerne Jitka and Niva. Acta Universitatis Agriculturae and Silviculturae Mendelianae Brunensis, 1996, 44, 19-23.

[38] Passioura, J. B. The transport of water from soil to shoot in wheat seedlings. Journal of Experimental Botany, 1980, 31, 333-345.

[39] Vamerali, T,, Saccomani, M., Bona, S., Mosca, G., Guarise, M., Ganis, A. A comparison of root characteristics in relation to nutrient and water stress in two maize hybrids. Plant and Soil, 2003, 255, 157-176. 
[40] Bänziger, M., Edmeades, G. O., Beck, D., Bellon, M. Breeding for drought and nitrogen stress tolerance in maize: From theory to Practice. Mexico, D. F., CIMMYT, 2000, $68 \mathrm{p}$.

[41] Chloupek, O., Forster, B. P., Thomas, W. T. B. The effect of semi-dwarf genes on root system size in field grown barley. Theoretical and Applied Genetics, 2006, 112, 779-786.

[42] Brown, A. L. P., Day, F. P., Stover, D. B. Fine root biomass estimates from minirhizotron imagery in a shrub ecosystem exposed to elevated $\mathrm{CO}_{2}$. Plant Soil, 2009, 317, 145-153.

[43] Muñoz-Romero, V., Benítez-Vega, J., López-Bellido, R. J., Fontán, J. M., López-Bellido, L. Effect of tillage system on the root growth of spring wheat. Plant Soil, 2010, 326, 97-107.

[44] Heřmanská, A., Středa, T., Chloupek, O. Improved wheat grain yield by a new method of root selection. Agronomy for Sustainable Development, 2015, 35, 195-202.

[45] Chloupek, O., Dostál, V., Středa, T., Psota, V., Dvořáčková, O. Drought tolerance of barley varieties in relation to their root system size. Plant Breeding, 2010, 129, 6, 630-636.

[46] Svačina, P., Středa, T., Chloupek, O. Uncommon selection by root system size increases barley yield. Agronomy for Sustainable Development, 2014, 34, 2, 545-551.

[47] Bouchereau, A., Clossais-Besnard, N., Bensaoud, A., Leport, L., Renard, M. Water stress effects on rapeseed quality. European Journal of Agronomy, 1996, 5, 1-2, 19-30.

[48] Lammerts van Bueren, E. T., Struik, P. C., Tiemens-Hulscher, M., Jacobsen, E. Concepts of Intrinsic Value and Integrity of Plants in Organic Plant Breeding and Propagation. Crop Science Society of America, 2003, 43, 1922-1929.

[49] Challinor, A. J., Ewert, F., Arnold, S., Simelton, E., Fraser, E. Crops and climate change: progress, trends, and challenges in simulating impact and informing adaptation. Journal of Experimental Botany, 2009, 60, 10, 2775-2789.

[50] Metzger, M. J., Bunce, R. G. H., Jongman, R. H. G., Mücher, C. A., Watkins, J. W. A climatic stratification of the environment of Europe. Global Ecology and Biogeography, $2005,14,6,549-563$.

[51] Sabaghnia, N., Dehghani, H., Alizadeh, B., Moghaddam, M. Yield analysis of rapeseed (Brassica napus L.) under water-stress conditions using GGE biplot methodology. Journal of Crop Improvement, 2011, 25, 1, 26-45.

[52] Baluska, F., Manusco, S. Plant- Environment Interactions. Springer Verlag, N.York, London, Heilderberg 2009.

[53] Baluska, F., Mancuso, S., Volkman, D. Communication in Plants: Neuronal Aspects of Plant Life. Springer Verlag, 2006. 
[54] Bláha, L., Pazderů, K. Importance of plant integrity in crop research, breeding, and production. Plant Signal \& Behavior, 2013, 8, 11, e27098, doi: 10.4161/psb.27098.

[55] Schenk, H. J., Callaway, R. M., Mahall, B. E. Spatial root segregation: Are plants territorial? Advances in Ecological Research, 1999, 28, 145-180.

[56] Alpi, A. et.al. Plant neurobiology: no brain, no gain? Trends in Plant Science, 2007, $12,4,135-136$.

[57] Bláha, L. Influence of seed quality on the root growth and development. In Proceedings of 7th International Symposium on Structure and Function of Roots. Nový Smokovec, Slovakia, 2011b, 32-33.

[58] Bláha, L. Vliv původu a odrůdy semen řepky na klíčivost v různých teplotních podmínkách. In Proceedings of 10th Scientific and Technical Seminar on Seed and Seedlings. Czech University of Life Science: Prague, 2011a, 164-168.

[59] Bláha, L., Vyvadilová, M., Janáček, J. Vliv odrůdy, lokality a př́pravy půdy na růst a vývoj kořenového systému řepky ozimé od zasetí do nástupu jarní vegetace. Význam pro růst a vývoj porostu. In Aktuální poznatky v pěstování, šlechtění, ochraně rostlin a zpracování produkti̊. Brno: VÚPT, 2009b, 12-13.

[60] Bláha, L., Vyvadilová, M., Klíma, M. Vliv vlastností semen na výnos vybraných genotypů řepky ozimé. In Nové poznatky z genetiky a šlachtenia polnohospodárskych rastlín. Zborník z 18. vedeckej konferencie. Pieštany: VÚRV, Slovakia, 2011, 69-71.

[61] Bláha, L., Vyvadilová, M., Klíma, M. Výběr genetických zdrojů řepky ozimé se zvýšenou suchovzdorností pomocí laboratorních testů. In Vliv abiotických a biotických stresorů na vlastnosti rostlin. Praha: VÚRV, 2009, 383-386.

[62] Vyvadilová, M., Klíma, M., Kučera, V., Prášil, I. T., Bláha, L. Výběr genetických zdrojů řepky ozimé se zvýšenou odolností ke stresovým faktorům vnějšího prostředí. In Aktuální poznatky v pěstování, šlechtění a ochraně rostlin. Brno: VÚPT, 2008, 157-160.

[63] Al-Barzinjy, M., Stølen, O., Christiansen, J. L. Comparison of growth, pod distribution and canopy structure of old and new cultivars of oilseed rape (Brassica napus L.). Acta Agriculturae Scandinavica, Section B - Soil \& Plant Science, 2003, 53, 3, 138-146.

[64] Sloane, D. H. G., Gill, G. S., McDonald, G. K. The impact of agronomic manipulation on early vigour in wheat on growth and yield in South Australia. Australian Journal of Agricultural Research, 2004, 55, 645-654

[65] Baluska, F. Plant Signaling. Springer Verlag, 2009.

[66] Kreps, J. A., Kay, S. A. Coordination of plant metabolism \& development by the circadian clock. Plant Cell, 1997, 9, 1235-1244.

[67] Garzón, F. C. The quest for cognition in plant neurobiology. Plant Signaling \& Behavior, 2007, 2, 208-211. 
